\title{
Variation in Maturation of Yellowtail Flounder (Pleuronectes ferruginea) on the Grand Bank
}

\author{
Stephen J. Walsh and M. Joanne Morgan \\ Northwest Atlantic Fisheries Center, Dept. of Fisheries and Oceans \\ P. O. Box 5667, St. John's, Newfoundland, Canada A1C 5X1
}

\begin{abstract}
Variation in the maturation of both male and female yellowtail flounder (Limanda ferruginea) on the Grand Bank was evident from analyses carried out on a cohort basis. Exploration of the effects of population size, growth, mortality, cohort strength and bottom temperature on maturation was carried out through statistical analyses of life history data collected during annual spring bottom trawl surveys from 1984 to 1997 . There was a pronounced declining trend in the onset of maturation in males but no directed trend in females. Increased growth of a cohort over its lifetime, increased growth in the year prior to maturation, increased mortality in adults and increased bottom temperatures all appear to exert some effect on maturation of one or both sexes. Population abundance did not appear to have any direct effect even though there has been a substantial decline in abundance during the study period which led to the implementation of a directed fishery moratorium in 1994. The significance of these findings is discussed in terms of life history theory.
\end{abstract}

Keywords: cohort, growth, maturity, mortality, reproduction, yellowtail flounder

\section{Introduction}

Natural variation in size and age at maturity within a population of a species can occur in stable populations but is generally small. However, within declining populations, large variations in maturation, as with other life history traits, have been reported in, for example, Atlantic cod, Gadus morhua, (Beacham, 1983a; Jørgensen, 1990), American plaice, Hippoglossoides platessoides, (Pitt, 1975; Morgan et al., MS 1996; Bowering et al., 1996, 1997) and North Sea plaice, Pleuronectes platessa and sole, Solea solea, (Rijnsdorp, 1989; Rijnsdorp and Vethaak, MS 1997). Also there may be large differences between different populations of the same species, for example Atlantic cod (Fleming, 1960; Godø and Moksness 1987), and American plaice (Roff, 1982; Walsh, 1994). Although some of these variations in size and age at maturity may reflect genetical changes (which are difficult to detect) others reflect changes in phenotypic plasticity. This plasticity is generally associated with changes in environmental conditions on the nursery grounds or later during the juvenile/adult stage (Alm, 1959, Carscadden and Leggett, 1975; Stearns and Crandall, 1984; Rijnsdorp, 1993a).
Stock productivity in marine fish is influenced by growth, maturation, mortality and fecundity. These life history traits are strongly correlated and governed by the energy budget of the fish. Roff (1984) concluded that these correlations are the result of adjusting the tradeoffs between growth, reproduction and survival. Changes in age-specific growth and survival rates have been shown to favour either an increase or a decrease in age at maturity (Roff, 1982; Stearns and Crandall, 1984, Stearns and Koella, 1986; Hutchings, 1993) and size at maturity (Reznick and Endler, 1982; Reznick et al., 1990; Kasperski and Kozlowski, 1993). For example, North Sea plaice with the highest juvenile growth rates mature at an earlier age and at a larger size than plaice which exhibited slower growth rates (Rijnsdorp, 1989). High mortality can also result in lowering of the age and size of maturity (Rinjsdorp and Ibelings, 1989; Policansky, 1993). Hutchings (1993) showed that in unexploited populations of brook trout (Salvelinus fontinalis) with low adult-to-juvenile mortality ratios, there was a delay in age at maturity compared to populations with higher ratios.

Changes in age and size at maturity have been recognized as one of the main biological indicators 
of stress in marine populations that have undergone serious declines (see Trippel, 1995 for a review). Rijnsdorp and Vethaak (MS 1997) showed that juvenile growth rates and fishing effort made significant contributions to the variation in maturation parameters of North Sea plaice and sole during their1960-95 study period. Natural- or fishery-induced declines in population size are thought to lead to an increase in growth rates, hence a reduction in age at maturity, as a result of reduced intra-specific competition for food (see for example Pitt, 1975; Power and Gregoire, 1978; Policansky, 1993; Rijnsdorp, 1993b; Rijnsdorp and Vethaak, MS 1997). This assumes that the compensatory response is density-dependent.

Yellowtail flounder (Pleuronectes ferruginea) is at its northern limit of commercial concentrations on the Grand Bank, off the east coast of Newfoundland (Walsh 1992). It is a relatively shortlived species with females growing older and larger than males. In the survey data, the historical maximum age of females is 13 years and size is 56 $\mathrm{cm}$ and for males it is 9 years and $48 \mathrm{~cm}$. However, in recent years there has been a truncation in age structure of females to age 9 . Values for age and length at $50 \%$ maturity in yellowtail flounder on the Grand Bank were first reported by Pitt (1970) from data collected during the period 1959 to 1968 . Males reached $A_{50}$ at 5.04 years with a $L_{50}$ of 31.3 $\mathrm{cm}$ and females reached $A_{50}$ at 6.12 years with a $L_{50}$ of $34.4 \mathrm{~cm}$. Using survey data for the 1975-95 period, Morgan and Walsh (MS 1997) reported that annual estimates of age $\left(A_{50}\right)$ and size $\left(L_{50}\right)$ at maturity of yellowtail flounder have shown a steady decline in both sexes from 1988-95. Coincident with this decline was a systematic decline in biomass from 217000 tons in 1984 to 56000 tons in 1994, and heavy fishing mortality on juveniles during the late-1980s and early-1990s (Walsh et al., 1995; Walsh et al., MS 1998). As the stock size declined in the late-1980s, there was a contraction in the northern range of the species (Brodie et al., 1998). In addition, there was a general cooling of bottom temperatures $\left(0.5\right.$ to $1.0^{\circ} \mathrm{C}$ below normal) and heat content ( $26 \%$ below normal) on the Grand Bank (Colbourne et al., 1997). Since 1995 the stock size has been increasing.

In this paper, we will examine the effects of temporal changes in population size, growth, mortality, cohort strength and temperature on variation in maturation of cohorts of yellowtail flounder. The time series shows sufficient contrast in population size, fishing mortality and environmental parameters to examine their influence on maturation.

\section{Materials and Methods}

\section{Data}

Data on life history parameters were collected during annual bottom trawl surveys of the Grand Bank, Northwest Atlantic Fisheries Organization (NAFO) Divisions 3L, 3N and 3O, from the spring period of 1984-97. These surveys employed a stratified random sampling design and were carried out mainly by the research vessel, $C C G$ Wilfred Templeman and, on occasion, by its sister ship, $C C G$ Alfred Needler. Because two different trawls have been used in these surveys, the 1984-95 catches were standardized to the new survey trawl, which came into use in 1996, using length-based conversion factors derived from comparative fishing experiments in 1996 (Walsh and Orr, MS 1998). These standardized values were used in the estimation of abundance, maturity, mean length at age, cohort strength and mortality. Morgan (1999) showed that trends in fish maturity are similar for converted and original survey data and there is no reason to suspect that the other parameters are influenced by gear effects.

For the analyses of life history traits and environmental variables only data from the southern Grand Bank, NAFO Div. 3N and 3O, were used. This is the area where the majority of the stock is concentrated and in some years there are no catches in the northern section of the Grand Bank, NAFO Div. 3L (Brodie et al., 1998).

\section{Maturity ogives}

Fish were classed as juvenile (immature) or adult (mature) using visual examination of gonads as described by Templeman et al. (1978). Proportions mature at age were calculated according to the method described by Morgan and Hoenig (1997) which corrects for bias introduced by lengthstratified sampling. Estimates of the age and size at $50 \%$ maturity $\left(A_{50}\right.$ and $\left.L_{50}\right)$ for each cohort were derived using a logistic model with a logit link function and binomial error. The data were fitted to the model using the Probit procedure of SAS (SAS, 1989). Values of $A_{50}$ and $L_{50}$ were produced only for those cohorts for which both the slope and intercept of the maturity ogive were significant at the $p=0.01$ level. 


\section{Hypotheses}

Variations in maturation were investigated by testing the following hypotheses:

a) cohorts experiencing lower population size matured at a younger age and smaller size;

b) cohorts experiencing higher growth matured at a younger age and smaller size;

c) cohorts experiencing higher mortality mature at a younger age and smaller size;

d) cohorts exhibiting lower year-class strength matured at a younger age and smaller size; and

e) cohorts experiencing higher temperature matured at a younger age and smaller size.

These hypotheses were set up to explore the effects of each parameter on the proportion mature at age and length.

\section{a) Population size effects}

For each year, stratified estimates of population abundance at age were used to calculate the mean total population size for each cohort during its lifetime (or the period during which it occurred in the survey if its entire life was not sampled). If the mean population abundance during the lifetime of the cohort was below or above the average for all cohorts then it was classified as occurring either during a low or high population abundance period. A similar approach was used on ages 1 to $A_{50}$ for each cohort and sex to examine effect of population abundance during the juvenile period.

\section{b) Growth effects}

Mean length-at-age was calculated by sex for each cohort ${ }^{1}$. For each sex the effect of age on mean length was modeled. The average of the residuals from this model was then calculated for each cohort. For each sex, cohorts with a mean residual greater than zero were considered to have higher than average growth, while those with a mean residual less than zero were considered to have lower than average growth. A similar procedure was carried out over ages 1 to $A_{50}$ for each cohort and sex to examine the effect of juvenile growth. The effect of growth on maturation was also examined by testing the effect of juvenile growth in the last year before maturation, i.e. the mean length at age 4 for males and age 5 for females.

\section{c) Mortality effects}

Adult mortality ${ }^{2}$ was calculated for each cohort as the number of fish age 8 in year $i$ divided by the number of fish of that cohort at age 9 in year $i+1$. Juvenile mortality ${ }^{3}$ was calculated as the number of fish of a cohort at age 3 in year $i$ divided by the number of fish of that cohort at age 4 in year $i+1$. These juveniles are not fully recruited age classes because of the selectivity of the survey gear, i.e. cohorts are not fully recruited to the gear until age 8. However, we assume that the selectivity of the gear remains proportionally constant from year to year and that annual estimates reflect changes in mortality.

Cohorts were classified as experiencing low or high mortality when compared to the average. The difference between the value for adult mortality and juvenile mortality served as a measure of the ratio of adult to juvenile mortality.

\section{d) Cohort strength effects}

The relative strength of each cohort was calculated using the general approach of Sinclair and Chouinard (MS 1991). The model took the form:

$$
\log \left(N_{i k t}\right)=\tau+\alpha_{i}+\delta_{k}+\varepsilon
$$

where: $N_{i k t}$ is number at age $i$ belonging to cohort $k$ in year $t$

$\tau$ is intercept

$\alpha_{i}$ is age effect for $i=3 \ldots .5$

$\delta_{k}$ is cohort effect

$\varepsilon$ is residuals from the fitted model

Cohorts were classed as having a relative strength less than the overall average or greater than the overall average.

\section{e) Environmental effects}

During the annual surveys, bottom temperature data were calculated at each fishing station using either mechanical bathyothermographs, expendable

\footnotetext{
1 These means were calculated correcting for bias introduced by the length-stratified sampling used (i.e. an adjusted age-length key was used).

2 Age 8 is the age at which yellowtail flounder are fully recruited to the survey trawl.

3 Age 3 is the first age represented in every year of the survey.
} 
bathyothermographs or trawl mounted Seabird-19 conductivity-temperature-depth (CTD) probes. The temperature at each fishing station was weighted by both fish abundance and total stratum area to calculate the average temperature occupied by the fish population as suggested by Perry and Smith (1994). The average temperature experienced over the lifetime of each cohort was then calculated for each sex. If the mean temperature during the lifetime of the cohort was below or above the average for all cohorts then it was classified as occurring either during a low or high temperature period. The same procedure was carried out for each cohort/sex combination for the juvenile period from birth to their respective $A_{50}$.

\section{Hypotheses testing}

The effect of cohort, average population size over a lifetime, average population size over the juvenile period, growth, juvenile growth, growth in the year prior to maturation, adult mortality, juvenile mortality, adult:juvenile mortality ratio, temperature over a lifetime, temperature over the juvenile period, and relative cohort strength on the proportion mature at age and size for each sex was explored using generalized linear models with a logit link function and binomial error (McCullagh and Nelder, 1983; SAS, 1993). Each model had the general form of:

$$
\text { pmat }=\log \left(\frac{u}{1-u}\right)
$$

where: pmat is proportion mature at age or length

$$
\begin{array}{cl}
u & \text { is } \tau+\alpha v_{i}+\beta_{j} \\
\tau & \text { is intercept } \\
v_{i} & \text { is age or length } \\
\alpha & \text { is age or length effect } \\
\beta_{j} & \text { is is effect of factor being examined } \\
& \quad \text { e.g. high or low population abun- } \\
& \text { dance }
\end{array}
$$

The statistical significance of each parameter examined was determined after first removing the effect of age or size. Each sex was tested separately. Because 48 tests were being conducted, increasing the likelihood of a significant result by chance alone, the significance level was adjusted so that only tests where $p<0.001$ were considered significant. Also, the proportion of the Deviance, i.e. the pseudocoefficient of determination $r^{2}$ (Swartzman et al., 1992; Swain, 1993), accounted for by each parameter was calculated. Only ages or lengths that had some contrast in the data were included, i.e. ages and lengths where all observations were mature or all were immature were excluded. For males, ages 4-7 and lengths $18.5-34.5 \mathrm{~cm}$ and for females, ages 5-8 and lengths $24.5-42.5 \mathrm{~cm}$ were used.

\section{Results}

There was a significant effect of cohort on maturity at age for both males ( $p=0.001$, pseudo $r^{2}$ $=0.52)$ and females $\left(p=0.0008\right.$, pseudo $\left.r^{2}=0.35\right)$. Males have shown a general decline in $A_{50}$ over the time period, with a high of 5.8 years for the 1979 cohort and a low of 4.6 years for the 1988 cohort, a decline of $21 \%$ (Fig. 1). Since the 1988 cohort, $A_{50}$ has increased to 4.9 years. Females showed less change, with a high of 6.8 years for the 1975 cohort and a low of 6.1 years for the 1987 cohort, a decline of only $10 \%$. As well, female maturity appeared to be more variable than male maturity with the trend over time less clear.

There was also a significant effect of cohort on maturity at length for both males ( $p=0.0001$, pseudo
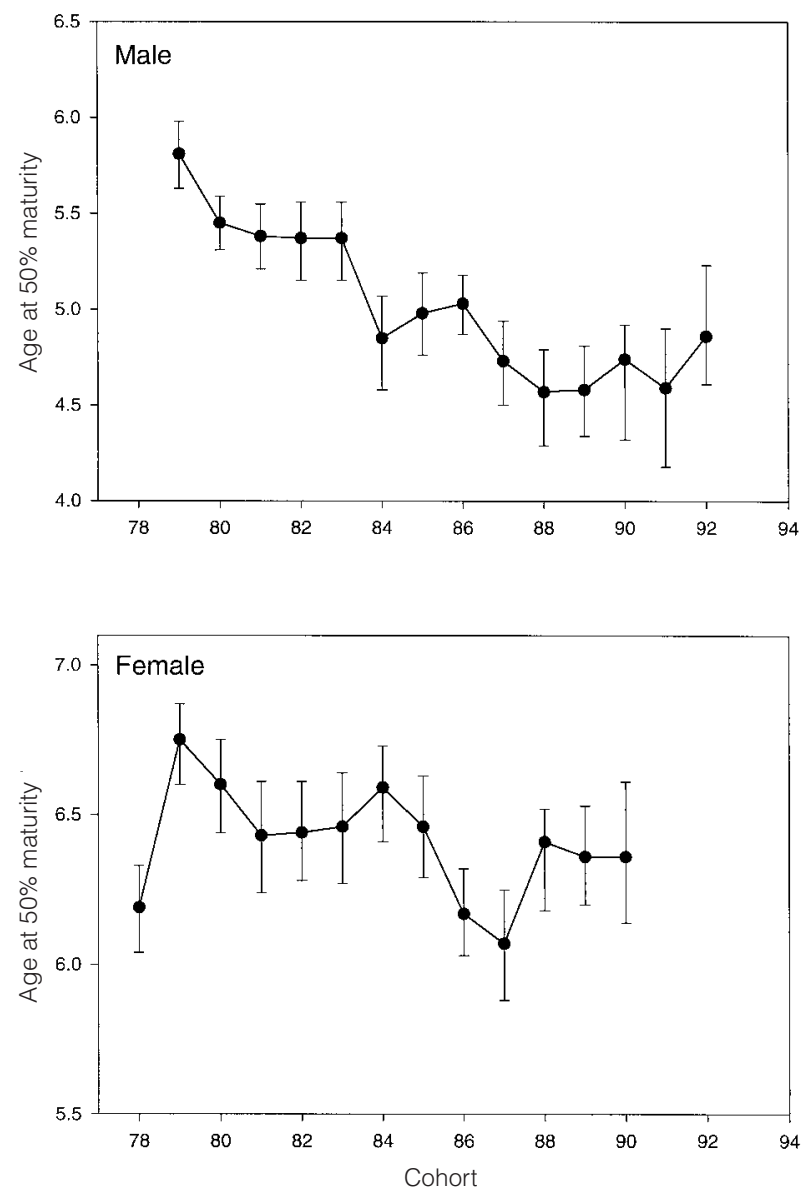

Fig. 1. Age at $50 \%$ maturity for male and female yellowtail flounder cohorts. (95\% fiducial limits are shown). 
$\left.r^{2}=0.45\right)$ and females $\left(p=0.0001, r^{2}=0.24\right)$. Male $L_{50}$ generally declined over the time period, from a high of $30.7 \mathrm{~cm}$ for the 1979 cohort to a low of 25.0 $\mathrm{cm}$ for the 1988 cohort, a decline of $18.5 \%$ (Fig. 2). Since the 1988 cohort, $L_{50}$ for males has increased slightly to $26.2 \mathrm{~cm}$. Female $L_{50}$ showed less of a consistent trend than the males and a smaller change over the time period. The largest $L_{50}$ was for the 1978 cohort at $34.9 \mathrm{~cm}$ and the smallest for the 1987 cohort at $32.5 \mathrm{~cm}$, a difference of $6.7 \%$. The $L_{50}$ for the 1991 cohort was $33.0 \mathrm{~cm}$.

There was no significant effect of population size on maturation when population size was examined over the lifetime of a cohort. Similarly, there was no effect during the juvenile period of a cohort (Table $1)$.

Growth over the lifetime of a cohort had a significant effect on maturity at length in males and
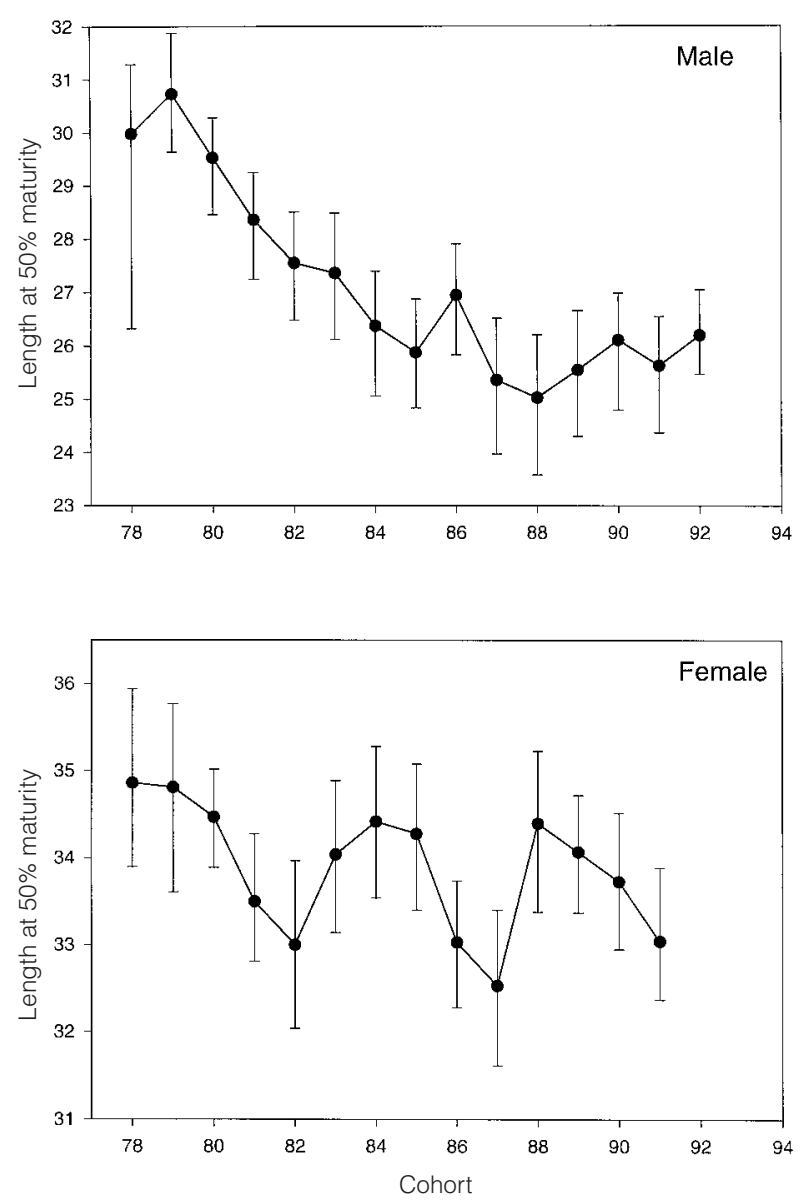

Fig. 2. Length at $50 \%$ maturity for male and female yellowtail flounder cohorts. (95\% fiducial limits are shown). approached significance in females (Table 1). Growth over the lifetime had a significant effect on maturity at age for males only. In general, cohorts with higher than average growth, matured at a younger age and a smaller size (Fig. 3 and 4). Growth over the juvenile period did not have a significant effect on maturity at age or size for either males or females. Growth in the last year before maturity, i.e. age 4 for males and age 5 for females, had a significant effect on maturity at age (but not size) in both sexes (Table 1). This meant that cohorts with higher than average growth in the year prior to maturation matured at a younger age (Fig. 5 and 6).

Adult mortality had a significant effect on maturity at length for males only (Table 1). Male cohorts with a higher than average adult mortality tended to mature at a smaller length (Fig. 7). There was no significant effect on the ratio of adult to juvenile mortality on maturation.

Relative cohort strength did not have a significant effect on maturity at age or size for either males or females (Table 1).

Male cohorts which experienced higher than average temperatures over their lifetime had a significantly higher proportion mature at age and length than those that experienced lower than average temperatures (Table 1, Fig. 8 and 9). There was no significant effect of temperature over the lifetime of the cohort on maturity in females or over the juvenile period in either sex.

In summary, it would appear that growth over the lifetime of the cohort, growth of the cohort in the year prior to maturation (age only), mortality (length only) and temperature had the greatest effect on maturity in males. For females, only the effect of growth over the lifetime of the cohort (length only) and growth of the cohort in the year prior to maturation (age only) showed any significant effect on maturation. None of the factors examined over the juvenile period had any significant effect. Those parameters that had a significant result also accounted for the largest proportion of the Deviance $\left(r^{2}\right)$.

\section{Discussion}

Variation in both size and age at maturity in the Grand Bank yellowtail flounder population was evident in both males and females during our 14year time series. Age and size at maturity are 
TABLE 1. Results of generalized linear models testing the significance of each variable on proportion mature at age and length. Because 48 separate tests were conducted, only tests with $p<0.001$ are considered significant. The pseudocoefficient of determination $\left(r^{2}\right)$ is also given for each test.

\begin{tabular}{|c|c|c|c|c|c|}
\hline Variable & & & & Male & Female \\
\hline \multirow[t]{8}{*}{ Abundance } & \multirow[t]{4}{*}{ AGE } & \multirow[t]{2}{*}{ Total } & $p$ & 0.0634 & 0.0997 \\
\hline & & & $r^{2}$ & 0.06 & 0.05 \\
\hline & & \multirow[t]{2}{*}{ Juvenile } & $p$ & 0.0265 & 0.0718 \\
\hline & & & $r^{2}$ & 0.09 & 0.06 \\
\hline & \multirow[t]{4}{*}{ LENGTH } & \multirow[t]{2}{*}{ Total } & $p$ & 0.7971 & 0.0333 \\
\hline & & & $r^{2}$ & 0.001 & 0.03 \\
\hline & & \multirow[t]{2}{*}{ Juvenile } & $p$ & 0.0055 & 0.0233 \\
\hline & & & $r^{2}$ & 0.06 & 0.04 \\
\hline \multirow[t]{12}{*}{ Growth } & \multirow[t]{6}{*}{ AGE } & \multirow[t]{2}{*}{ Total } & $p$ & 0.0002 & 0.0076 \\
\hline & & & $r^{2}$ & 0.20 & 0.12 \\
\hline & & \multirow[t]{2}{*}{ Juvenile } & $p$ & 0.1879 & 0.3108 \\
\hline & & & $r^{2}$ & 0.03 & 0.02 \\
\hline & & \multirow[t]{2}{*}{ Age 4 or 5} & $p$ & 0.0005 & 0.0001 \\
\hline & & & $r^{2}$ & 0.17 & 0.23 \\
\hline & \multirow{6}{*}{ LENGTH } & \multirow{2}{*}{ Total } & $p$ & 0.0001 & 0.0012 \\
\hline & & & $r^{2}$ & 0.14 & 0.07 \\
\hline & & \multirow[t]{2}{*}{ Juvenile } & $p$ & 0.0846 & 0.6147 \\
\hline & & & $r^{2}$ & 0.02 & 0.002 \\
\hline & & \multirow[t]{2}{*}{ Age 4 or 5} & $p$ & 0.0026 & 0.3012 \\
\hline & & & $r^{2}$ & 0.07 & 0.01 \\
\hline \multirow[t]{12}{*}{ Mortality } & \multirow[t]{6}{*}{ AGE } & \multirow[t]{2}{*}{ Adult } & $p$ & 0.016 & 0.4223 \\
\hline & & & $r^{2}$ & 0.13 & 0.01 \\
\hline & & \multirow{2}{*}{ Juvenile } & $p$ & 0.0739 & 0.1434 \\
\hline & & & $r^{2}$ & 0.07 & 0.05 \\
\hline & & \multirow[t]{2}{*}{ adlt:juv } & $p$ & 0.0505 & 0.2081 \\
\hline & & & $r^{2}$ & 0.12 & 0.05 \\
\hline & \multirow[t]{6}{*}{ LENGTH } & \multirow[t]{2}{*}{ Adult } & $p$ & 0.0006 & 0.2218 \\
\hline & & & $r^{2}$ & 0.11 & 0.01 \\
\hline & & \multirow[t]{2}{*}{ Juvenile } & $p$ & 0.1867 & 0.1156 \\
\hline & & & $r^{2}$ & 0.02 & 0.02 \\
\hline & & adlt:juv & $p$ & 0.0064 & 0.8663 \\
\hline & & & $r^{2}$ & 0.10 & 0 \\
\hline Cohort Strength & AGE & & $p$ & 0.8889 & 0.7363 \\
\hline & & & $r^{2}$ & 0 & 0.002 \\
\hline & LENGTH & & $p$ & 0.8584 & 0.9659 \\
\hline & & & $r^{2}$ & 0 & 0 \\
\hline Temperature & AGE & Total & $p$ & 0.0001 & 0.0968 \\
\hline & & & $r^{2}$ & 0.26 & 0.05 \\
\hline & & Juvenile & $p$ & 0.0318 & 0.6026 \\
\hline & & & $r^{2}$ & 0.09 & 0.006 \\
\hline & LENGTH & Total & $p$ & 0.0001 & 0.1060 \\
\hline & & & $r^{2}$ & 0.18 & 0.02 \\
\hline & & Juvenile & $p$ & 0.6658 & 0.4105 \\
\hline & & & $r^{2}$ & 0.002 & 0.006 \\
\hline
\end{tabular}



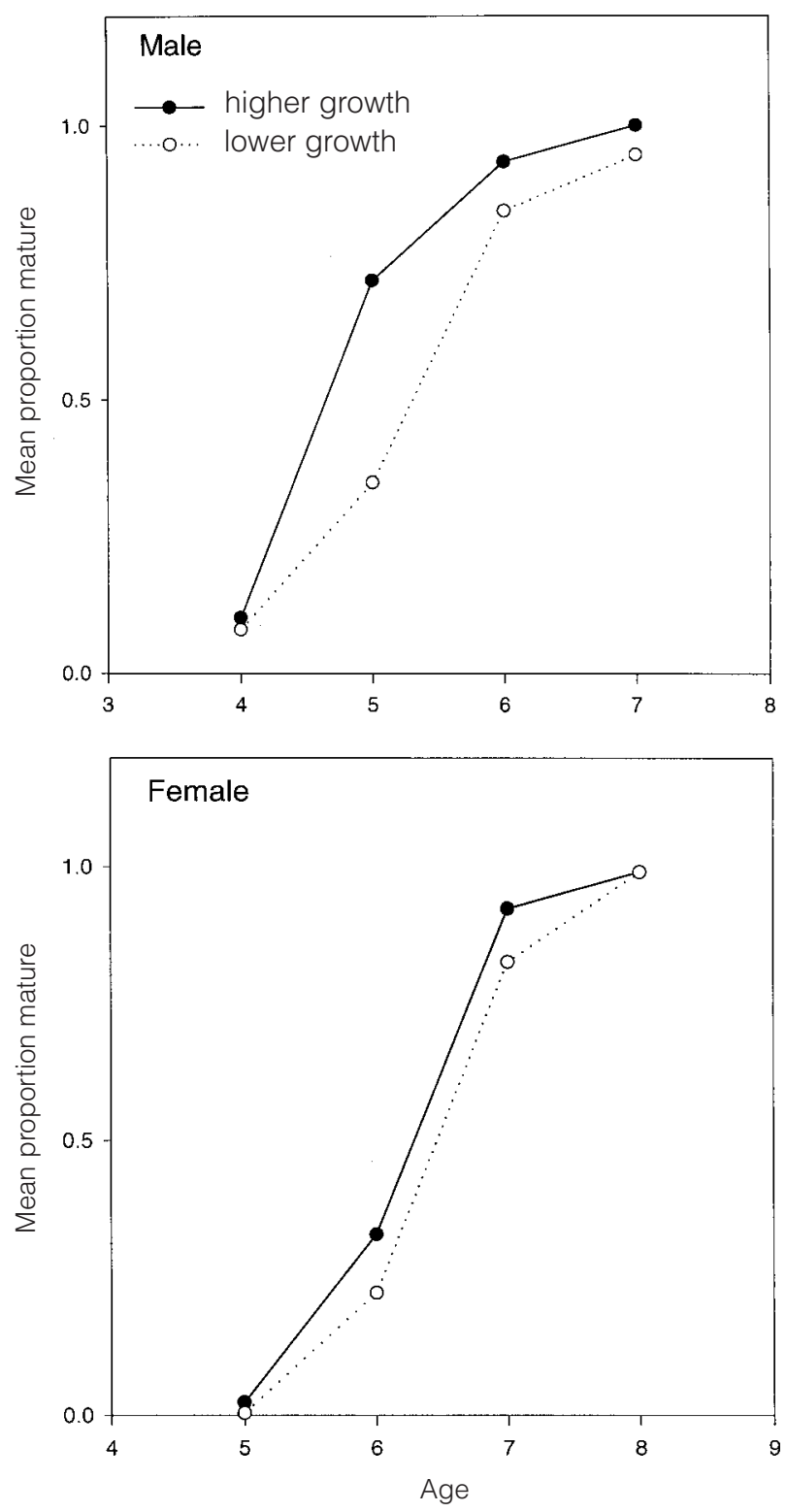

Fig. 3. Mean proportion mature at each age for cohorts that had a higher than average growth during their lifetime (solid circles) and those experiencing a lower than average growth during their lifetime (open circles).

strongly correlated in both sexes. However, only males showed a distinct declining trend; females varied around the long term average for both parameters. Although there was a $21 \%$ decline in $A_{50}(\bar{X}=5.04 \mathrm{yr}$. $)$ in males and a $10 \%$ decline in $A_{50}(\bar{X}=6.12$ yr. $)$ in females, the overall mean values are similar to those reported by Pitt (1970) for the 1959-68 period, $5.04 \mathrm{yr}$. and $6.44 \mathrm{yrs}$.
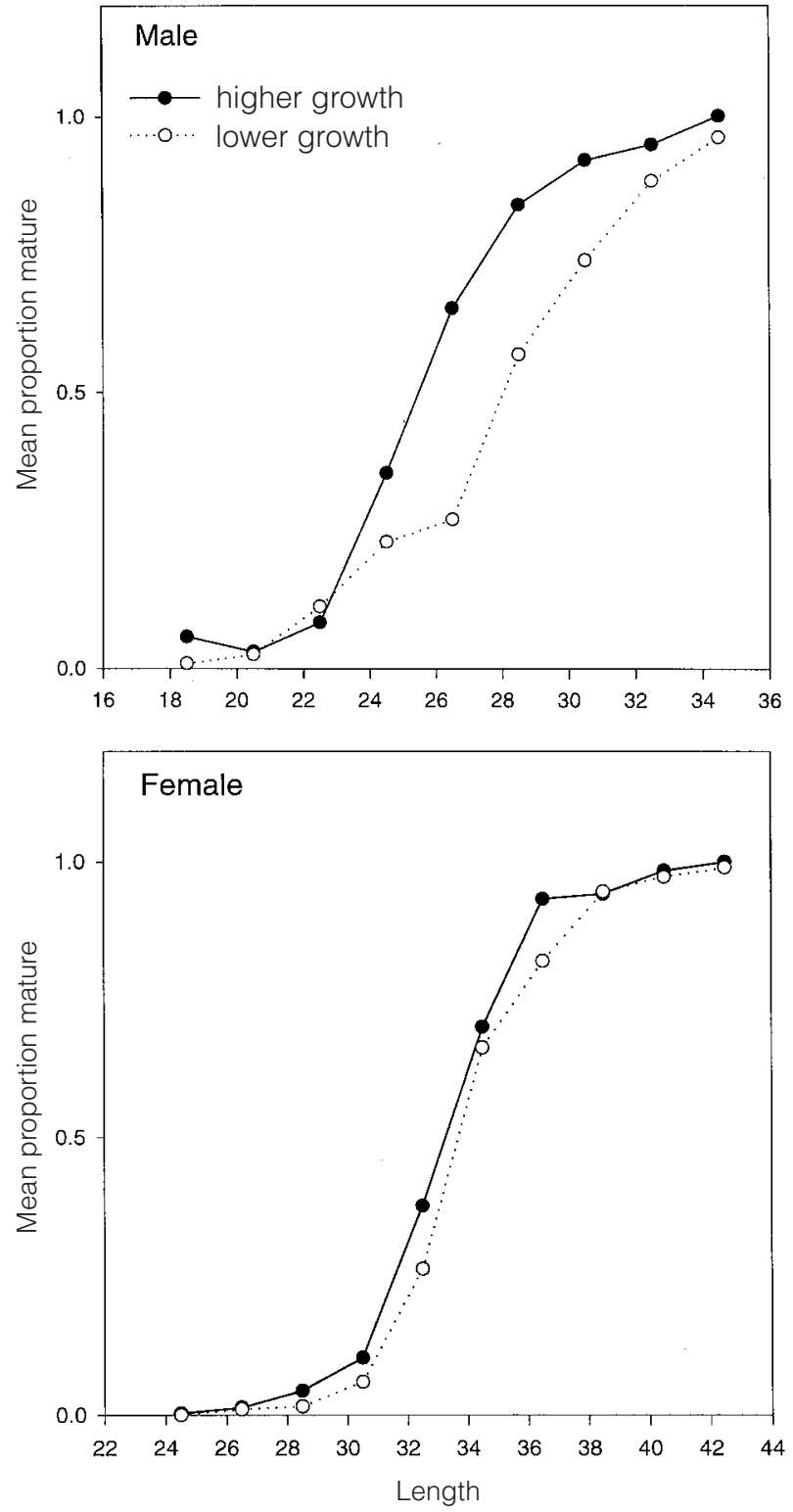

Fig. 4. Mean proportion mature at each length for cohorts that had a higher than average growth during their lifetime (solid circles) and those experiencing a lower than average growth during their lifetime (open circles).

respectively. There was an $18.5 \%$ decline in $L_{50}$ in males $(\bar{X}=27.1 \mathrm{~cm})$ and a $6.7 \%$ decline in $L_{50}$ in females $(\bar{X}=33.9 \mathrm{~cm})$ over our study period. Although the overall average size of maturity for males was $13 \%$ below that value $(\bar{X}=31.3 \mathrm{~cm})$ reported for Pitt (1970), there was no difference in overall mean $L_{50}$ in females between the two study periods $(33.9 \mathrm{~cm}$ for $1984-95$ and $34.4 \mathrm{~cm}$ for 

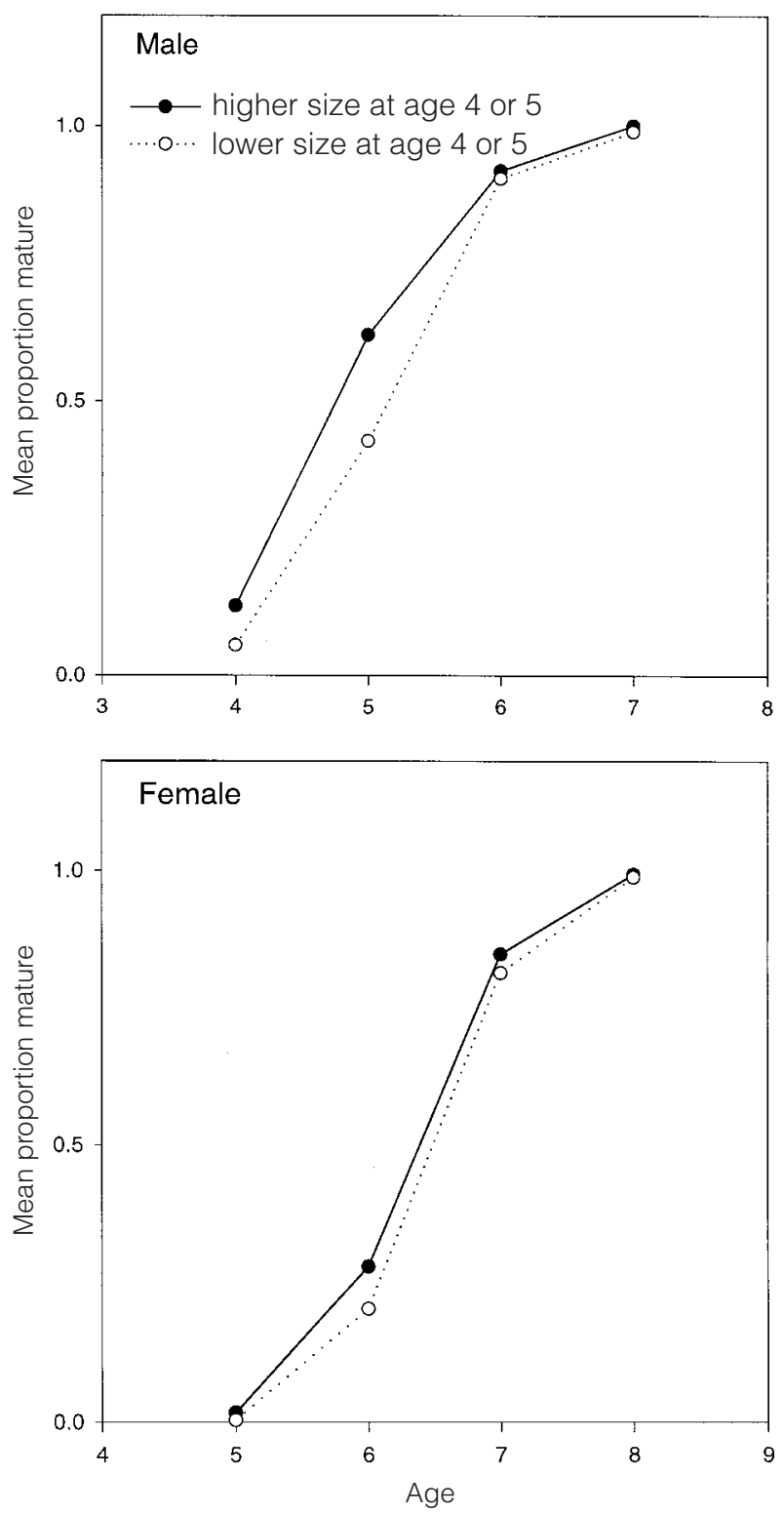

Fig. 5. Mean proportion mature at each age for cohorts that had a higher than average growth in the year prior to maturation (age 4 males, age 5 females; solid circles) and those experiencing a lower than average growth in the year prior to maturation (open circles).

1959-68). Most studies of marine fishes support the concept that variations in size and age at maturity occur in both sexes and similar trends are expected, i.e. if there is a decreasing trend in either size and/ or age it occurs in both sexes (see for example Morgan et al., MS 1996, MS 1997). Such is not the case in this study; males appear to show a declining trend that is absent in females.
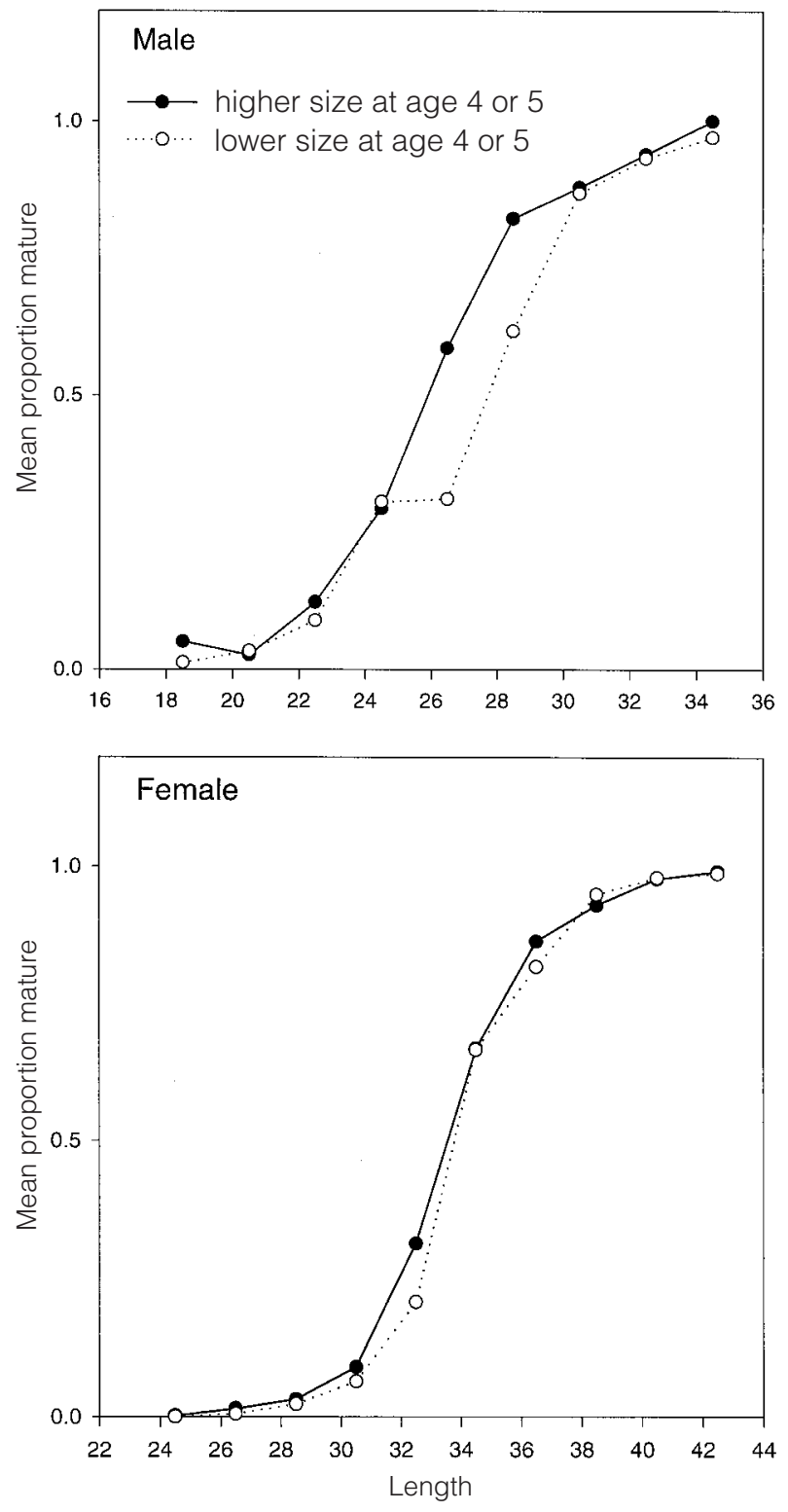

Fig. 6. Mean proportion mature at each length for cohorts that had a higher than average growth in the year prior to maturation (age 4 males, age 5 females; solid circles) and those experiencing a lower than average growth in the year prior to maturation (open circles).

Spatial differences in maturation of yellowtail flounder are evident when the Grand Bank population is compared to other yellowtail flounder populations further south on the Scotian Shelf, Georges Bank, Cape Cod Bank, and the southern New England Bank. Yellowtail flounder on these southern banks mature at a smaller size and age than the Grand Bank population (Pitt, 1970). There is 

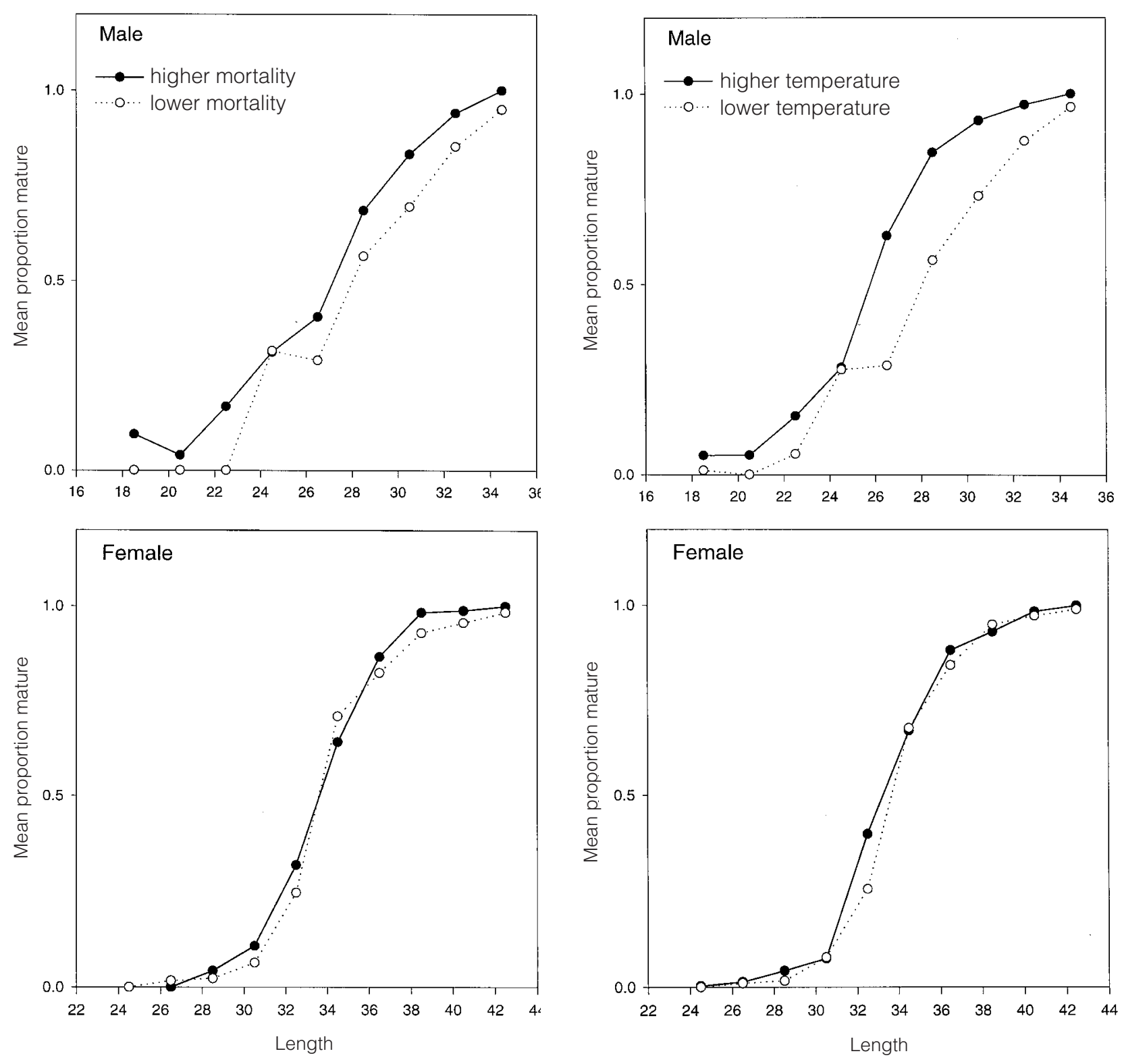

Fig. 7. Mean proportion mature at each length for cohorts that had a higher than average relative mortality (solid circles) and those experiencing a lower than average relative mortality (open circles).

also evidence to suggest that within one of these populations, both males and females have shown declines in average size at maturity over time. Royce et al. (1959) estimated mean size at first maturity in males and females at $26 \mathrm{~cm}$ and $32 \mathrm{~cm}$ respectively, in the southern New England population. For the 1985-90 period, O'Brien et al.

Fig. 8. Mean proportion mature at each length for cohorts that experienced higher than average temperatures (solid circles) and those experiencing a lower than average temperatures (open circles).

(1993) estimated the mean size at first maturity in males and females at $19.6 \mathrm{~cm}$ and $25.5 \mathrm{~cm}$, respectively, for the same population. Mean age at maturity in these studies showed little variation.

Changes in the onset of maturation are generally correlated with changes in population 

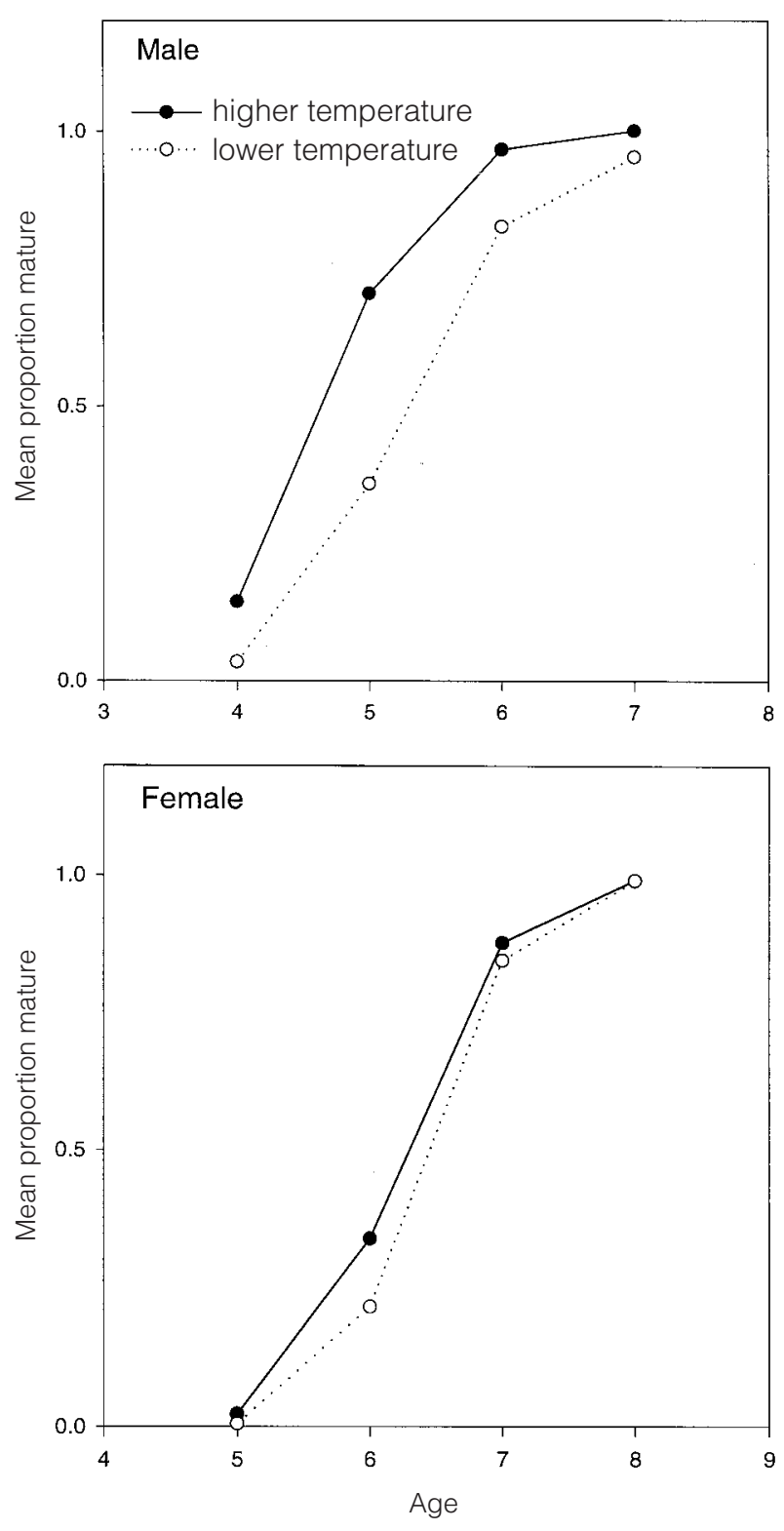

Fig. 9. Mean proportion mature at each age for cohorts that experienced higher than average temperatures (solid circles) and those experiencing a lower than average temperatures (open circles).

size, growth, mortality and to some extent environmental conditions under the assumption that these changes are related to a density-dependent compensatory effect. Declines in age and size at first maturity are often associated with natural- or fishery-induced reduction in population size (Craig, 1982; Stearns and Crandall, 1984; Rijnsdorp, 1989; Kasperski and Kozlowski, 1993; Policansky, 1993; Rowell, 1993). For example, large declines in age and size at maturity at a time of large declines in population abundance were evident in American plaice on the Grand Bank during the same study period and also in two other plaice populations off the northeast and south coasts of Newfoundland (Morgan et al., MS 1996, MS 1997; Bowering et al., 1996, 1997). However, population size appeared not to have any regulatory effect on maturation of male and female yellowtail flounder, even though there was a significant decline in stock size during the study period due to overfishing and poor recruitment (Walsh et al., 1995, MS 1998). In addition, our analysis did not demonstrate any significant effect of cohort strength on maturation even though there were large variations in the abundance of individual cohorts.

Growth over the lifetime of yellowtail flounder cohorts had a significant effect on size at maturation in both sexes and age at maturity in males only. Higher growth led to early maturity (males only) and a reduction in size at maturity. Although fish with faster juvenile growth rates are expected to mature earlier than slow growing fish (Alm, 1959; Nikoloskii, 1969; Roff, 1982; Rijnsdorp, 1989; Hutchings, 1993), our analysis showed that only high growth in the year prior to maturation, not over the entire juvenile period, resulted in a reduction in age at maturity but not size. On the other hand, Rijnsdorp (1993a) concluded that maturation in North Sea plaice depended upon length reached within a certain year and also on growth in the three preceding years. For many species, size may be the most critical factor in maturation (Alm, 1959; Roff, 1981, 1982, 1991; Rijnsdorp, 1993a) and variation in age at maturity reflects the variation in growth in the year prior to maturation. This is likely the case for yellowtail flounder on the Grand Bank.

The cost of reproduction is influenced by schedules of growth, survival and fecundity that shape the age and size at maturity (Williams, 1966; Charlesworth, 1980; Bell and Koufopanou, 1986; Gadgil and Bossert, 1970, Roff, 1984, 1991; Hutchings, 1993). Size-dependent survival is thought to underline size dependent maturity (Roff, 1982; 1991; Hutchings, 1993). High mortality in male, but not in female, yellowtail flounder resulted in a decrease in size at maturity. Although high adult mortality relative to juveniles should favor a decrease in maturity (Gadgil and Bossert, 1970; Reznick et al., 1990; Hutchings, 1993), neither high adult mortality relative to juvenile mortality or high 
juvenile mortality had any detectable effect on maturation in our study. Differences in size (age) selectivity of the sampling trawl could have affected these mortality estimates.

Environmental conditions, such as temperature, have been shown to affect growth rates and hence the onset of maturation (Gunter, 1950; Alm, 1959; Carscadden and Leggett, 1975; Beacham, 1983b; Godø and Moksness, 1987; Sandstrom et al., 1995; Walsh, 1994). Male yellowtail flounder cohorts experiencing higher than average temperatures during their lifetime matured at a younger age and smaller size. Such was not the case for females. In addition, no effect of temperature was detected during the juvenile period. Although an increase in growth had some effect on the age and size of maturity in both males and females, a temperature effect on size and age at maturity was detected in males only.

In this study of yellowtail flounder on the Grand Bank, detectable effects of growth, mortality and temperature, but not population size or cohort strength, on maturation were evident. However, these effects were not consistent between sexes. Sexual dimorphism in life history traits of many marine fishes is common with males maturing earlier and at a smaller size, having a shorter lifespan and a smaller asymptotic length than females. This may be due to differences in the pattern of allocating surplus energy into growth and reproduction between males and females. Early maturation of males results in a switch of available energy reserves from growth to reproduction. This difference in allocation of energy between males and females may affect the level of sensitivity of a particular reproductive trait to be influenced by such parameters as density, growth, mortality and temperature. Female yellowtail flounder in this study are less responsive than males to the various influencing factors studied. It is possible that females are more constrained than males in minimum levels of energy, size and/or age required to mature. Such a physio-logical constraint, if it exists, could explain why there is a lack of plasticity in female responses. Differences in mean size and age at maturity for male yellowtail flounder, but not for females, have also been detected in other populations on Georges Bank, Cape Cod Bank and the southern New England Bank (O'Brien et al., 1993). This may be a common feature in yellowtail flounder populations.

\section{Acknowledgements}

Special thanks to Mike Ross and an anonymous reviewer for providing comments on an earlier draft of this manuscript.

\section{References}

ALM, G. 1959. Connections between maturity, size and age in fishes. Rep. Inst. Fresh. Res., 40: 5-145.

BEACHAM, T. D. 1983a. Variability in median size and age at sexual maturity of Atlantic cod, Gadus morhua, on the Scotian shelf in the northwest Atlantic ocean. Fish. Bull., 81: 303-321.

1983 b. Variability in size and age at sexual maturity of American plaice and yellowtail flounder in the Canadian Maritimes region of the northwest Atlantic ocean. Can. Tech. Rep. Fish. Aquat. Sci., 1196, $74 \mathrm{p}$.

BELL, G., and V. KOUFOPANOU. 1986. The cost of reproduction. In: Oxford Surveys and Evolutionary Biology 3, R. Dawkins and M. Ridley [eds.] Oxford University Press, Oxford England. p. 83-1131.

BOWERING, W. R., W. B. BRODIE, and M. J. MORGAN. 1996. Changes in abundance and certain population parameters of American plaice on St. Pierre Bank off Newfoundland during 1972-1994, with implications for fisheries management. $N$. Amer. J. Fish. Man., 16: 747-769.

BOWERING, W. R., M. J. MORGAN, and W. B. BRODIE. 1997. Changes in the population of American plaice (Hippoglossoides platessoides) off Labrador and northeastern Newfoundland: a collapsing stock with low exploitation. Fish. Res., 30: 199-216.

BRODIE, W. B., S. J. WALSH, and D. B. ATKINSON. 1998. The effect of stock abundance on range contraction of yellowtail flounder (Pleuronectes ferruginea) on the Grand Bank of Newfoundland in the Northwest Atlantic from 1975-1995. J. Sea Res., 39: 139-152.

CARSCADDEN, J. E., and W. C. LEGGETT. 1975. Life history variations in populations of American shad, Alosa sapidissima (Wilson), spawning in the tributaries of the St. John River, New Brunswick. J. Fish. Biol., 7: 595-609.

COLBOURNE, E., B. DE YOUNG, S. NARAYANAN, and J. HELBIG. 1997. Comparison of hydrography and circulation on the Newfoundland Shelf during 1990-1993 with the long-term mean. Can. J. Fish. Aquat. Sci., 54(Suppl. 1): 68-80.

CHARLESWORTH, B. 1980. Evolution in an AgeStructured Population. Cambridge University Press, Cambridge, England.

CRAIG, J. F. 1982. Population dynamics of Windermere perch. In: $50^{\text {th }}$ Annual Report of the Freshwater Biological Association. Ambleside: FBA. p. 49-59.

FLEMING, A. M. 1960. Age, growth and sexual maturity of cod (Gadus morhua L.) in the Newfoundland area, 
1947-1950. J. Fish. Res. Board Can., 17: 775-809.

GADGIL, M., and W. H. Bossert. 1970. Life historical consequences of natural selection. Amer. Nat., 104: $1-24$.

GOD, , O. R., and E. MOKSNESS. 1987. Growth and maturation of Norwegian coastal cod and the Northeast Arctic cod under different conditions. Fish. Res., 5: 235-242.

GUNTER, G. 1950. Correlation between temperature of water and size of marine fishes on the Atlantic and Gulf coasts of the United States. Copeia, 4: 298304.

HUTCHINGS, J. A. 1993. Adaptive life histories effected by age-specific survival and growth rate. Ecology, 74: 673-684.

JØRGENSEN, T. 1990. Long-term changes in age at sexual maturity of northeast Arctic cod (Gadus morhua L.). ICES J. Cons., 46: 235-248.

KASPERSKI, W., and J. KOZLOWSKI. 1993. The effect of exploitation on size at maturity in laboratory populations of guppies Poecilia reticulata (Peters). Acta Hydrobiol., 35: 65-72.

McCULLAGH, P. and J. A. NELDER. 1983. Generalized Linear Models. Chapman and Hall, London.

MORGAN, M. J. 1999. The effect of a change in perception of length distribution on maturity-at age, weight-at-age and spawning stock biomass. $J$. Northw. Atl. Fish. Sci., 25: 141-150 (this volume).

MORGAN, M. J., and J. M. HOENIG. 1997. Estimating maturity-at-age from length stratified sampling. $J$. Northw. Atl. Fish. Sci., 21: 51-63.

MORGAN, M. J., and S. J. WALSH. MS 1997. Observations on maturation, recruitment and spawning biomass in yellowtail flounder on the Grand Bank. NAFO SCR Doc., No.71, Serial No. N2905, 7 p.

MORGAN, M. J., W. B. BRODIE, S. J. WALSH, D. POWER, and D. ORR. MS 1996. An assessment of the American plaice stock in Divisions 3LNO. NAFO SCR Doc., No. 75, Serial No. N2750, 31 p.

MORGAN, M. J., W. B. BRODIE, S. J. WALSH, and D. ORR. MS 1997. An assessment of Divisions 3LNO American plaice. NAFO SCR Doc., No. 60, Serial No. N2894, 47 p.

NIKOLSKII, G. V. 1969. Fish Population Dynamics. Oliver and Boyd, Edinburgh, 232 p.

O'BRIEN, L., J. BURNETT, and R. K. MAYO. 1993. Maturation of nineteen species of finfish off the Northeast coast of the United States, 1985-1990. NOAA Tech. Rep. NMFS, 113: 66 p.

PERRY, R. I., and S. J. SMITH. 1994. Identifying habitat associations of marine fishes using survey data: an application to the northwest Atlantic. Can. J. Fish. Aquat. Sci., 51: 589-602.

PITT, T. K. 1970. Age composition and growth of yellowtail flounder (Limanda ferruginea) from the Grand Bank, J. Fish. Res. Board Can., 31: 18001802 .

1975. Changes in abundance and certain biological characteristics of Grand Bank American plaice, Hippoglossoides platessoides. J. Fish. Res. Board Can., 32: 1383-1398.

POLICANSKY, D. 1993. Fishing as a cause of evolution in fishes. In: The Exploitation of Evolving Resources, T. K. Stokes, J. M. McGlade and R. Law [eds]. Springer-Verlag, Berlin. p. 2-18.

POWER, G. and J. GREGOIRE. 1978. Predation by freshwater seals on the fish community of lower Seal Lake, Quebec. J. Fish. Res. Board Can., 35: 844850.

REZNICK, D., and J. ENDLER. 1982. The impact of predation on life history evolution in Trinidadian guppies (Poecilia reticulata). Evol., 36: 160-177.

REZNICK, D. N., H. BRYGA, and J. A. ENDLER. 1990. Experimentally induced life history evolution in a natural population. Nature, 346: 357-359.

RIJNSDORP, A. D. 1989. Maturation of male and female North Sea plaice (Pleuronectes platessa L.). ICES J. Cons., 46: 35-51.

1993a. Relationship between juvenile growth and the onset of sexual maturity of female North Sea plaice, Pleuronectes platessa. Can. J. Fish. Aquat. Sci., 50: 1617-1631.

1993b. Fisheries as a large-scale experiment on life-history evolution: disentangling phenotypic and genetic effects in changes in maturation and reproduction of North Sea plaice, Pleuronectes platessa L. Oecologia, 96: 391-401.

RIJNSDORP, A. D. and B. IBELINGS. 1989. Sexual dimorphism in the energetics of reproduction and growth of North Sea plaice, Pleuronectes platessa L. J. Fish. Biol., 35: 401-415.

RIJNSDORP, A. D., and A. D. VETHAAK. MS 1997. Changes in reproductive parameters of North Sea plaice and sole between 1960-1995. ICES C.M. Doc., No. U:14, 31 p.

ROFF, D. A. 1981. Reproductive uncertainty and the evolution of interoparity: why don't flatfish put all their eggs in one basket? Can. J. Fish. Aquat. Sci., 38: $968-977$.

1982. Reproductive strategies in flatfish: a first synthesis. Can. J. Fish. Aquat. Sci., 39: 1686-1698.

1984. The evolution of life history parameters in teleosts. Can. J. Fish. Aquat. Sci., 41: 984-1000.

1991. The evolution in life-history variation in fishes, with particular reference to flatfishes. Neth. J. Sea. Res., 27: 197-207.

ROWELL, C. A. 1993. The effects of fishing on the timing of maturity in North Sea cod (Gadus morhua L.). In: The Exploitation of Evolving Resources, T. K. Stokes, J. M. McGlade and R. Law [eds.] Springer-Verlag, Berlin. p. 44-62.

ROYCE, W. F., R. J. BUTLER, and E. D. PREMETZ. 1959. Decline of the yellowtail flounder (Limanda ferruginea) off New England. U.S. Fish Wild. Serv. Fish. Bull., 146: 169-267.

SANDSTROM, O., E. NEUMAN, and G. THORESSON. 1995. Effects of temperature on life history variables 
in perch. J. Fish Biol., 47: 652-670.

SINCLAIR, A., and G. CHOUINARD. MS 1991. Analysis of research survey catch at age data using a multiplicative model. ICES C.M. Doc., No. D:39, 8 p.

SAS INSTITUTE INC. 1989. SAS/STAT Users Guide. SAS Institute Inc., Cary, NC.

1993. SAS Technical Report P-243, SAS/STAT Software: The GENMOD Procedure, Release 6.09. SAS Institute Inc, Cary, NC.

STEARNS, S. C., and R. E. CRANDALL. 1984. Plasticity for age and size at sexual maturity: a life history response to unavoidable stress. In: Fish Reproduction: Strategies and Tactics, G. W. Potts and R. J. Wootton [eds.] New York: Academic Press. p. 2-33.

STEARNS, S. C., and J. C. KOELLA. 1986. The evolution of phenotypic plasticity in life-history traits: predictions of reaction norms for age and size at maturity. Evolution, 40: 893-913.

SWAIN, D. P. 1993. Age- and density-dependent bathymetric pattern of Atlantic cod (Gadus morhua) in the southern Gulf of St. Lawrence. Can. J. Fish. Aquat. Sci., 50: 1255-1264.

SWARTZMAN, G., C. HUANG, and S. KALUZNY. 1992. Spatial analysis of Bering Sea groundfish survey data using generalized additive models. Can. J. Fish. Aquat. Sci., 49: 1366-1378.

TEMPLEMAN, W., V. M. HODDER, and R. WELLS. 1978. Sexual maturity and spawning in haddock, Melanogrammus aeglefinus, of the southern Grand Bank. ICNAF Res. Bull., 13: 53-65.

TRIPPEL, E. A. 1995. Age at maturity as a stress indicator in fisheries. Bio. Sci., 45: 759-771.
WALSH, S. J. 1992. Factors influencing distribution of juvenile yellowtail flounder (Limanda ferruginea) on the Grand Bank off Newfoundland. Neth. J. Sea Res., 29: 193-203.

1994. Life history traits and spawning characteristics in populations of long rough dab (American plaice) Hippoglossoides platessoides (Fabricius) in the north Atlantic. Neth. J. Sea Res., 32: 241-254.

WALSH, S. J., and D. ORR. MS 1998. Conversion factors for yellowtail flounder survey indices derived from comparative fishing trials between the Engel 145 otter trawl and the Campelen 1800 shrimp trawl. NAFO SCR Doc., No. 60, Serial No. N3052, 10 p.

WALSH, S. J., W. B. BRODIE, C. BISHOP, and E. MURPHY. 1995. Fishing on juvenile groundfish nurseries on the Grand Bank: a discussion of technical measures of conservation In: Proceedings of a symposium on Marine Protected Areas and Sustainable Fisheries, N. L. Shackell and J. H. Martin Willison [eds.]. Second International Conference on Science and the Management of Marine Protected Areas, Dalhousie University, 1620 May 1994. Acadia University, Nova Scotia. p. 54-73.

WALSH, S. J., W. B. BRODIE, M. VEITCH, D. ORR, C. McFADDEN, and D. MADDOCK-PARSONS. MS 1998. An assessment of the Grand Bank yellowtail flounder stock in NAFO Divisions 3LNO. NAFO SCR Doc., No. 72, Serial No. N3064, 79 p.

WILLIAMS, G. C. 1966. Natural selection, the costs of reproduction and refinement of Lack's principle. Am. Nat., 100: 687-690. 
